\title{
Sistem Informasi Rekam Medis Pada Klinik PT. Nippon Paint Jakarta
}

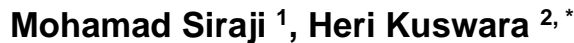 \\ ${ }^{1}$ Sistem Informasi; STMIK Nusa Mandiri ; Warung Jati Barat (Margasatwa), \\ JI. Damai No.8, Jakarta Selatan, telp : (021) 78839513; e-mail: \\ sirajimuhammad@gmail.com \\ 2.Sistem Informasi Akuntansi; Universitas Bina Sarana Informatika; Jl. Kamal Raya \\ No.18, Cengkareng, Kota Jakarta Barat, Daerah Khusus Ibukota Jakarta; e-mail: \\ heri.hrk@bsi.ac.id \\ *Korespondensi: e-mail: heri.hrk@bsi.ac.id \\ Diterima: 29 Mei 2020; Review: 30 Mei 2020; Disetujui: 6 Juni 2020; Diterbitkan: 17 Juni 2020

\begin{abstract}
Medical record is a file that contains records and documents about patient identity, examination, treatment, actions and other services that have been provided to patients in health care facilities. Problems that occur in the Clinic PT. Nippon Paint Jakarta is an ineffective and efficient management of medical data. This information system aims to manage medical data quickly and accurately. This system development method uses SDLC by making UML diagrams such as use case diagrams, class diagrams, activity diagrams, entity relationship diagrams as stages of system design. This information system is based on WEB using the PHP programming language supported by SQL database. The results of the design of this system are expected to be one of the solutions to the problems that have occurred so far.
\end{abstract}

Keywords: Clinic, Medical Records, Informations Systems

\begin{abstract}
Abstrak
Rekam medis adalah berkas yang berisi catatan dan dokumen tentang identitas pasien, pemeriksaan, pengobatan, tindakan dan pelayanan lain yang telah diberikan kepada pasien pada sarana pelayanan kesehatan. Permasalahan yang terjadi di Klinik PT. Nippon Paint Jakarta yaitu pengelolaan data medis yang kurang efektif dan efisien. Sistem informasi ini bertujuan supaya pengelolaan data medis dapat berjalan dengan cepat dan tepat. Metode pengembangan sistem ini menggunakan SDLC dengan membuat diagram-diagram UML seperti use case diagram, class diagram, activity diagram, entity relationship diagram sebagai tahapan perancangan sistem. Sistem informasi ini dibuat dengan berbasis WEB menggunakan bahasa pemrograman PHP yang didukung basis data SQL. Hasil rancang bangun sistem ini diharapkan dapat menjadi salah satu solusi dari permasalahan yang terjadi selama ini.
\end{abstract}

Kata kunci: Klinik, Rekam Medis, Sistem Informasi

\section{Pendahuluan}

Sistem informasi, yang kadang kala disebut sebagai sistem pemrosesan data, merupakan sistem buatan manusia yang biasanya terdiri dari sekumpulan komponen (baik manual maupun berbasis komputer) yang terintegrasi untuk mengumpulkan, menyimpan, dan mengelola data serta menyediakan informasi mengenai saldo persediaan. (Anastasia Diana, 2011). Teknologi informasi saat ini merupakan kebutuhan yang sangat penting bagi organisasi 


\section{Mohamad Siraji, Heri Kuswara}

atau perusahaan. Perkembangan teknologi dan perkembangan ilmu pengetahuan memicu banyak kalangan untuk mencari alternatif pemecahan masalah dibidang teknologi sistem informasi. Teknologi infomasi saat ini merupakan kebutuhan yang sangat penting bagi organisasi atau perusahaan. Teknologi informasi telah banyak digunakan untuk berbagai aspek seperti manajemen dan sumber daya manusia. (Susanto, 2018). Dapat disimpulkan bahwa sistem Teknologi informasi merupakan kumpulan data yang terintegritasi, bersinergi dan saling melengkapi serta diolah untuk menghasilkan keluaran dalam menyelesaikan permasalahan dan pengambilan keputusan.

Didalam Peraturan Pemerintah Republik Indonesia Nomor 47 Tahun 2016 Tentang Fasilitas Pelayanan Kesehatan, Pasal 1 dijelaskan bahwa Fasilitas Pelayanan Kesehatan adalah suatu alat dan/atau tempat yang digunakan untuk menyelenggarakan upaya pelayanan kesehatan, baik promotif, preventif, kuratif maupun rehabilitatif yang dilakukan oleh Pemerintah, pemerintah daerah, dan/atau masyarakat. Sementara pada pasal 4 dijelaskan bahwa Jenis Fasilitas Pelayanan Kesehatan terdiri atas: (a) tempat praktik mandiri Tenaga Kesehatan; (b) pusat kesehatan masyarakat; (c) klinik; (d) rumah sakit; (e) apotek; (f) unit transfusi darah; (g) laboratorium kesehatan; (h) optikal; (i) fasilitas pelayanan kedokteran untuk kepentingan hukum; dan (j). Fasilitas Pelayanan Kesehatan tradisional. Sementara pada Pasal 12 dijelaskan bahwa (1) Pemerintah Daerah kabupaten/kota menentukan jumlah klinik berdasarkan kebutuhan masyarakat terhadap pelayanan kesehatan pada 1 (satu) wilayah. (2) Penentuan kebutuhan sebagaimana dimaksud pada ayat (1) dilakukan melalui penetapan rasio antara jumlah klinik dibanding dengan jumlah penduduk. (3) Rasio sebagaimana dimaksud pada ayat (2) ditetapkan dengan pertimbangan sebagai berikut: (a) kondisi geografis dan aksesibilitas masyarakat; (b) tingkat utilitas; (c) jam kerja pelayanan; dan (d) jumlah praktik mandiri dokter/dokter gigi atau dokter spesialis/dokter gigi spesialis di wilayah tersebut. (Peraturan Pemerintah Republik Indonesia Nomor 47 Tahun 2016 Tentang Fasilitas Pelayanan Kesehatan, https://www.persi.or.id/images/regulasi/pp/pp472016.pdf)(Peraturan Pemerintah Republik Indonesia Nomor 47 Tahun 2016 Tentang Fasilitas Pelayanan Kesehatan, n.d.)

Dalam Permenkes No: 269/MENKES/PER/III/2008 yang dimaksud rekam medis adalah berkas yang berisi catatan dan dokumen antara lain identitas pasien, hasil pemeriksaan, pengobatan yang telah diberikan, serta tindakan dan pelayanan lain yang telah diberikan kepada pasien. (Peraturan Menteri Kesehatan Republik Indonesia. Nomor 269/MENKES/PER/III/2008. Tentang. Rekam Medis. http://pelayanan.jakarta.go.id/download/regulasi/peraturan-meneteri-kesehatan-nomor-269tentang-rekam-medis.pdf)(Peraturan Menteri Kesehatan Republik Indonesia. Nomor 269/MENKES/PER/II/2008. Tentang. Rekam Medis, n.d.)

Ruang rekam medis dapat dikatakan baik apabila ruangan tersebut menjamin keamanan dan terhindar dari ancaman kehilangan, kelalaian, bencana dan segala sesuatu yang dapat membahayakan rekam medis tersebut. (Siswanti, 2019), 
Pada praktik pribadi dokter, perekaman data rekam medis pasien masih menggunakan media konvensional, data rekam medis pasien ditulis pada kertas dan dikumpulkan didalam suatu wadah atau lemari. Resiko pada penerapan metode pengelolaan data rekam medis ini adalah kerusakan fisik pada kertas, akses yang sulit pada rekam medis dengan harus berada pada klinik, dan jumlah waktu pengelolaan yang dibutuhkan semakin besar seiring dengan jumlah rekam medis yang semakin banyak. (Yusrizal, Rahmad Dawood, 2017).

\section{Metode Penelitian}

Pada metode ini penulis mengumpulkan data dan melakukan pengamatan kegiatan dalam permintaan data mengenai Rekam Medis PT. Nippon Paint Jakarta. Penulis memperoleh informasi dari PT. Nippon Paint Jakarta tentang masalah yang dipilih dengan cara sesi tanya jawab dengan bagian IT di Klinik tersebut. Segala upaya yang dilakukan oleh peneliti untuk memperoleh dan menghimpun segala informasi tertulis yang relevan dengan masalah yang diteliti. Informasi ini diperoleh dari sumber - sumber lain. Serta melakukan searching pada internet.

Proses pengumpulan kebutuhan diintensifkan dan difokuskan, khususnya pada perangkat lunak. Pada analisis kebutuhan pengguna dibagi menjadi dua, diantaranya: analisis kebutuhan User, dan analisis kebutuhan Sistem.

Setelah memahami analisa kebutuhan software maka tahapan selanjutnya adalah melakukan perancangan design. Proses design akan menerjemahkan syarat kebutuhan sebuah perancangan perangkat lunak yang sebelum dibuat coding, proses ini berfokus pada struktur data, arsitektur perangkat lunak, representasi interface dan detail (algoritma) procedural. Serta peralatan UML ( Unified Modeling Language) merancang mendokumentasikan sistem piranti lunak. UML yang menawarkan sebuah standart untuk merancang model sebuah sistem. Dengan menggunakan UML Dapat dibuat model untuk semua jenis aplikasi piranti lunak, dimana aplikasi tersebut dapat berjalan pada piranti keras, sistem operasi dan jaringan apapun, serta ditulis dalam bahasa pemrograman apapun.

Adapun peralatan pendukung lainnya yang digunakan dalam pembuatan skripsi ini yaitu dengan ERD atau yang disebut juga dengan Entity Relationship Diagram. ERD merupakan suatu model untuk menjelaskan hubungan antar data dalam basis data berdasarkan objekobjek dasar data yang mempunyai hubungan antar relasi. ERD untuk memodelkan struktur data dan hubungan antar data, untuk menggambarkannya digunakan beberapa notasi dan simbol. Pada dasarnya ada tiga simbol yang digunakan, yaitu : entity, atribut, hubungan atau relasi. Dan sedangkan dalam mendesain database yang digunakan adalah SQL Server adalah sebuah sistem manajemen basis data relasional.

Yang dimaksud perancangan disini adalah membuat pemodelan yang meliputi, perancangan Database, Software Architecture dan User Interface berikut penjabaran dari masing - masing perancangan design: 


\section{Mohamad Siraji, Heri Kuswara}

\section{Desain Database (basis data)}

Pada proses ini data - data yang digunakan disimpan ke dalam database (basis data) Untuk merancang basis datanya, dilakukan perancangan tabel - tabel atau record store yang digunakan untuk menyimpan data yaitu diantaranya menggunakan ERD (Entity Relationship Diagram) dan LRS (Logical Relational Structural) ke dalam basis data dan Menampilkan struktur basis data.

2. Desain Software Architecture

Pada proses ini menggunakan metode Unified Modelling Language (UML) Untuk memudahkan pembangunan sistem berbasis object oriented.

Tools yang digunakan pada UML ini meliputi :
a. Perancangan Use Case Diagram
b. Perancangan Activity Diagram
c. Perancangan Class Diagram
d. Perancangan Sequence Diagram

3. Desain Interface (User Interface)

Pada Proses ini melakukan perancangan pada user interface dari sistem yang akan dibangun. Perancangan tersebut meliputi halaman - halaman yang ada didalam sistem.

\section{Code generation}

Setelah melakukan analisa dan perancangan sistem, selanjutnya saatnya sistem di implementasikan. Pada tahap ini terdapat beberapa aktivitas yang dilakukan. Aktivitas - aktivitas yang dimaksud adalah Pemrograman. Pada tahap ini hasil desain dimasukkan kedalam bentuk Bahasa pemrograman yang digunakan agar dapat dijalankan dalam bentuk aplikasi. Adapun Software yang digunakan dalam pembuatan sistem ini adalah Macromedia Dreamweaver CS8 sebagai software editor, XAMPP versi 3.2.2 yang mencakup apache versi 2.4.25 untuk web server PHP versi 5.6.30 untuk Bahasa pemrogramannya, dan SQL Server 2012 untuk Databasenya.

d. Testing

Testing adalah pengujian eksternal fungsional untuk menemukan kesalahankesalahan dan memastikan bahwa input akan memberikan hasil yang aktual dan sesuai.

e. Support

Support System dengan menyediakan berbagai informasi yang diperlukan yang dibutuhkan oleh karyawan PT. Nippon Paint Jakarta.

Model Waterfall jika didefinisikan secara literature berarti air terjun. Namun bagi ilmu komputer dan juga teknologi informasi, waterfall merupakan salah satu jenis model yang digunakan untuk pengembangan sebuah perangkat lunak atau sistem. model ini merupakan model pengembangan sistem yang setiap tahapan 
pengembangannya dilakukan secara berurutan.

\section{Hasil dan Pembahasan}

\subsection{Proses Bisnis Sistem Berjalan}

Syarat untuk kunjungan klinik ini Pasien harus terdaftar terlebih dahulu sebagai karyawan PT. Nippon Paint Paint Jakarta. Kemudian setelah mendaftar Admin Klinik akan mencatat persyaratan pasien tersebut. Langkah selanjutnya pencatatan masuk kedalam sistem untuk pemeriksaan oleh Dokter Klinik. Berikutnya setelah selesai pemeriksaan rekam medis oleh dokter klinik kemudian bagian Apotek adalah mengkonfirmasi data pemberkasan rekam medis melalui sistem ke admin dan memberikan obat melalui resep dokter klinik dari informasi sistem tersebut. Setelah pasien menerima obat selesai kunjungan ke klinik maka laporan kunjungan pasien tersebut tersimpan secara langsung ke dalam sistem.

Berikut Activity diagram sistem Informasi Rekam Medis Pada Klinik PT. Nippon Paint Jakarta dapat dilihat pada gambar 1.

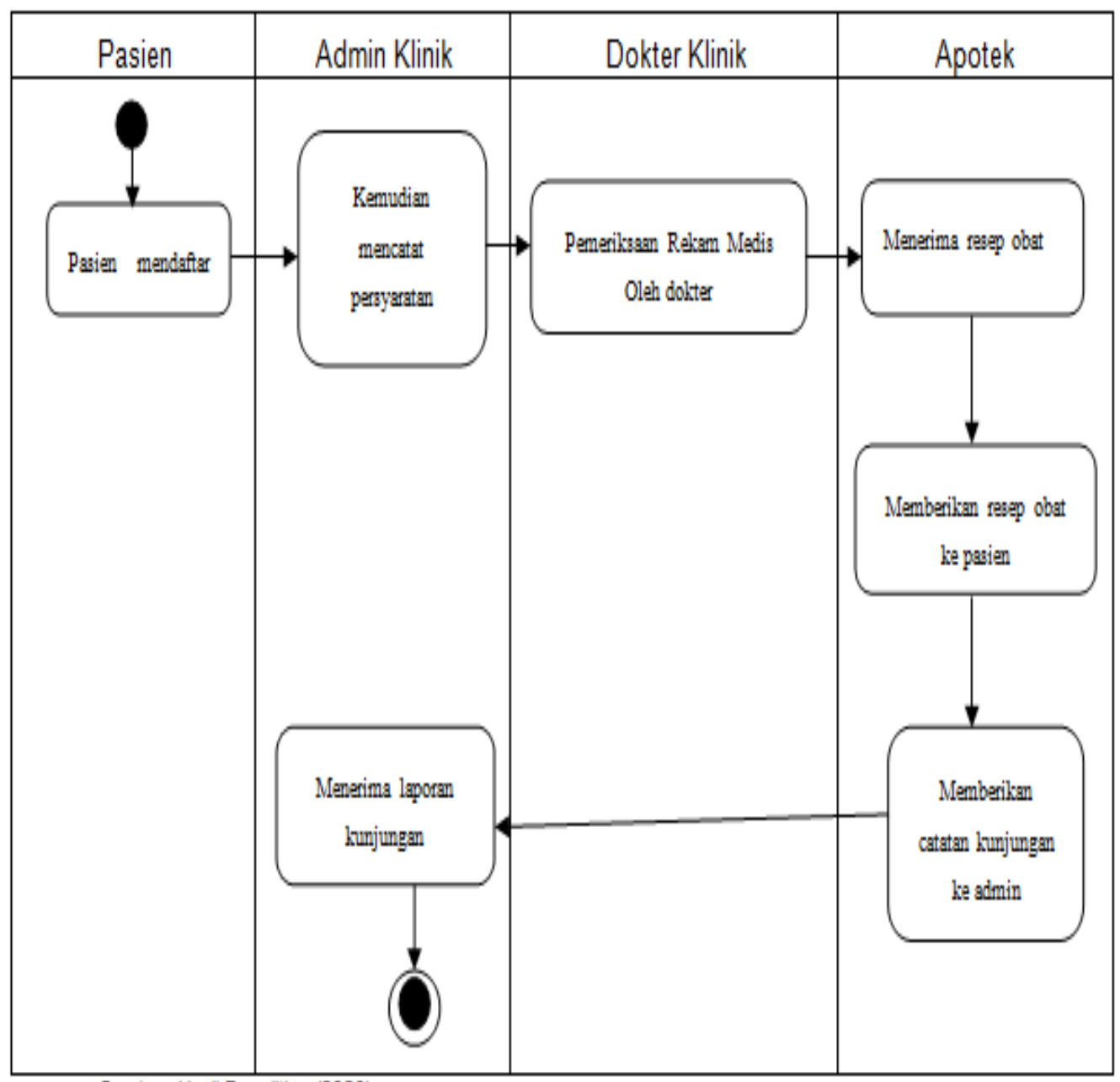

Sumber: Hasil Penelitian (2020)

Gambar 1. Activity Diagram Proses Bisnis Kunjungan pasien. 


\subsection{Tahapan Analisis}

Penggunaan sistem terkomputerisasi pada sebuah instansi bertujuan untuk menambah kelancaran dalam proses pengolahan data. Selain itu sistem terkomputerisasi dapat mengurangi permasalahan yang berkaitan dengan hilang atau rusaknya data dan meminimalisir kesalahan dalam pengolahan data. Berikut spesifikasi kebutuhan dari sistem informasi rekam medis:

\section{Halaman Hrd :}

A1 dapat mencari identitas pegawai

A2 dapat menambah pegawai

A3 dapat mengubah data pegawai

\section{Halaman Admin :}

B1 dapat menambah pasien

B2 dapat mencari data pasien

B3 dapat mendaftarkan kunjungan

B4 dapat melihat daftar kunjungan

B5 dapat mencari identitas dokter

B6 dapat menambah dokter

B7 dapat mengubah data dokter

B8 dapat menambah obat

B9 dapat mencari obat

B10 dapat melakukan stok opname

B11 dapat mencari user

B12 dapat menambah user

B13 dapat mengubah data user

B14 dapat melihat laporan

B15 dapat mencetak laporan

\section{Halaman dokter :}

C1 dapat memeriksa kunjungan

\section{Halaman Apotek :}

D1 dapat menerima resep obat

\section{A. Usecase Diagram}

Use Case diagram ini dibuat untuk menggambarkan perilaku dan mendeskripsikan interaksi antara satu atau lebih aktor dengan sistem informasi yang telah dibuat. Berikut use case diagram halaman Admin: 


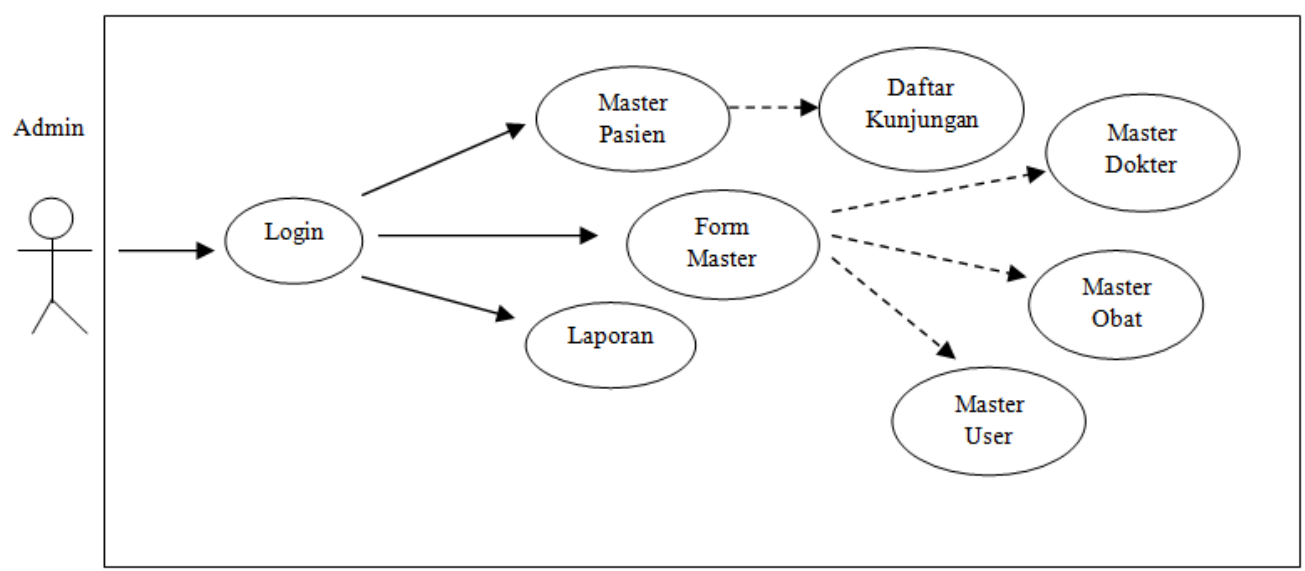

Sumber: Hasil Penelitian (2020)

Gambar 2. Use Case Diagram Halaman Admin

\section{B. Activity Diagram}

Activity diagram berfungsi untuk mendeskripsikan suatu aktivitas yang dikerjakan mulai dari awal sampai tahapan akhir. Berikut activity diagram Admin Klinik:

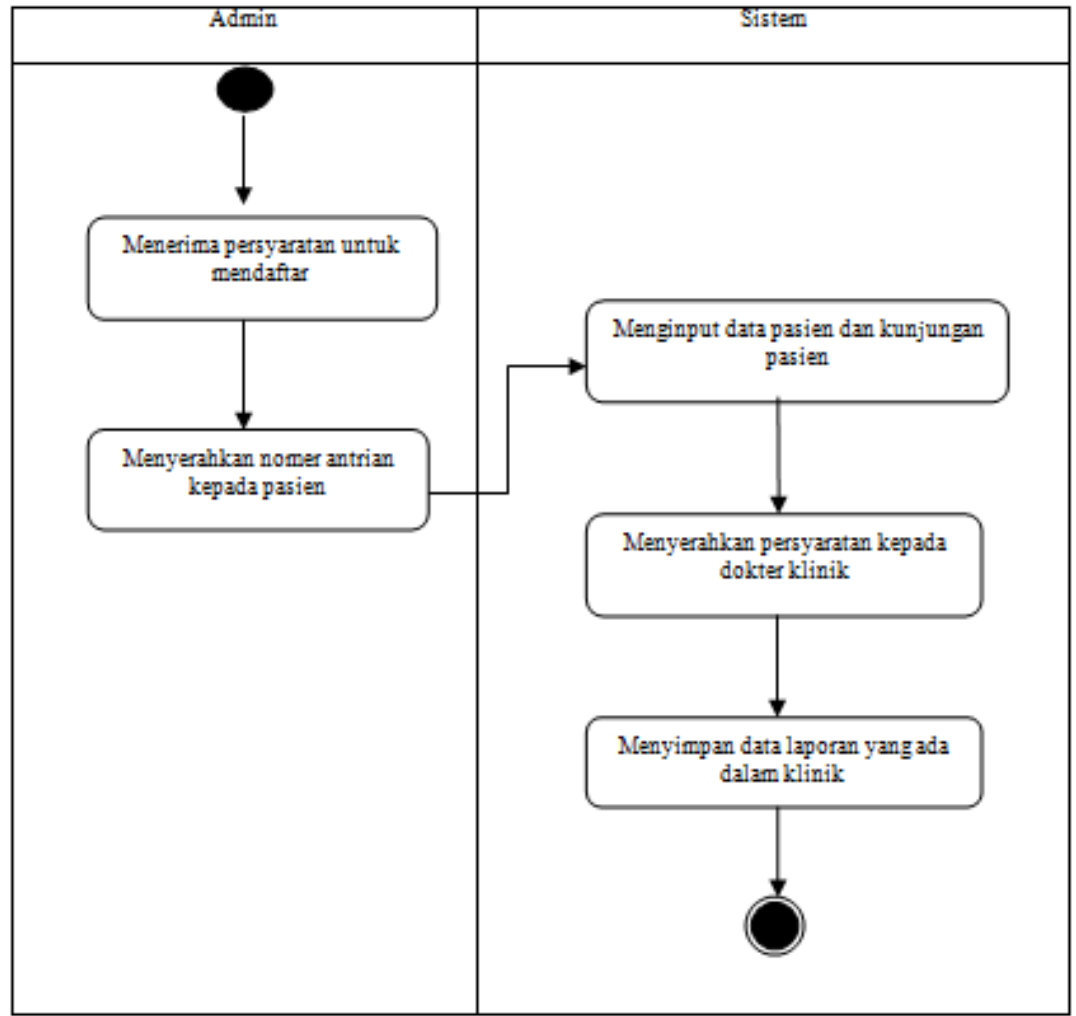

Sumber: Hasil Penelitian (2020)

Gambar 3. Activity Diagram Admin Klinik

Pada Gambar 3 terlihat aktifitas admin terhadap sistem yang dimulai dari menerima persyaratan pasien dalam mendaftar, menyerahkan nomer antrian kepada pasien lalu pada 


\section{Mohamad Siraji, Heri Kuswara}

sistem melakukan penginputan data pasien dan kunjungan pasien, menyerahkan persyaratan kepada dokter klinik dan menyimpan data laporan.

\section{Class Diagram}

Class Diagram adalah sebuah spesifikasi yang jika di implementasikan akan menghasilkan sebuah objek dan merupakan inti dari pengembangan dan desain berorientasi objek. Class Diagram menggambarkan struktur sistem dari segi pendefinisian kelas - kelas yang memiliki atribut, metode ataupun operasi (Sukamto \& Shalahuddin, 2013). Class Diagram menggambarkan keadaan atribut suatu sistem, sekaligus menawarkan layanan untuk memanipulasi keadaan tersebut. Berikut Class Diagram dari Sistem Informasi Rekam Medis Pada Klinik PT. Nippon Paint Jakarta.

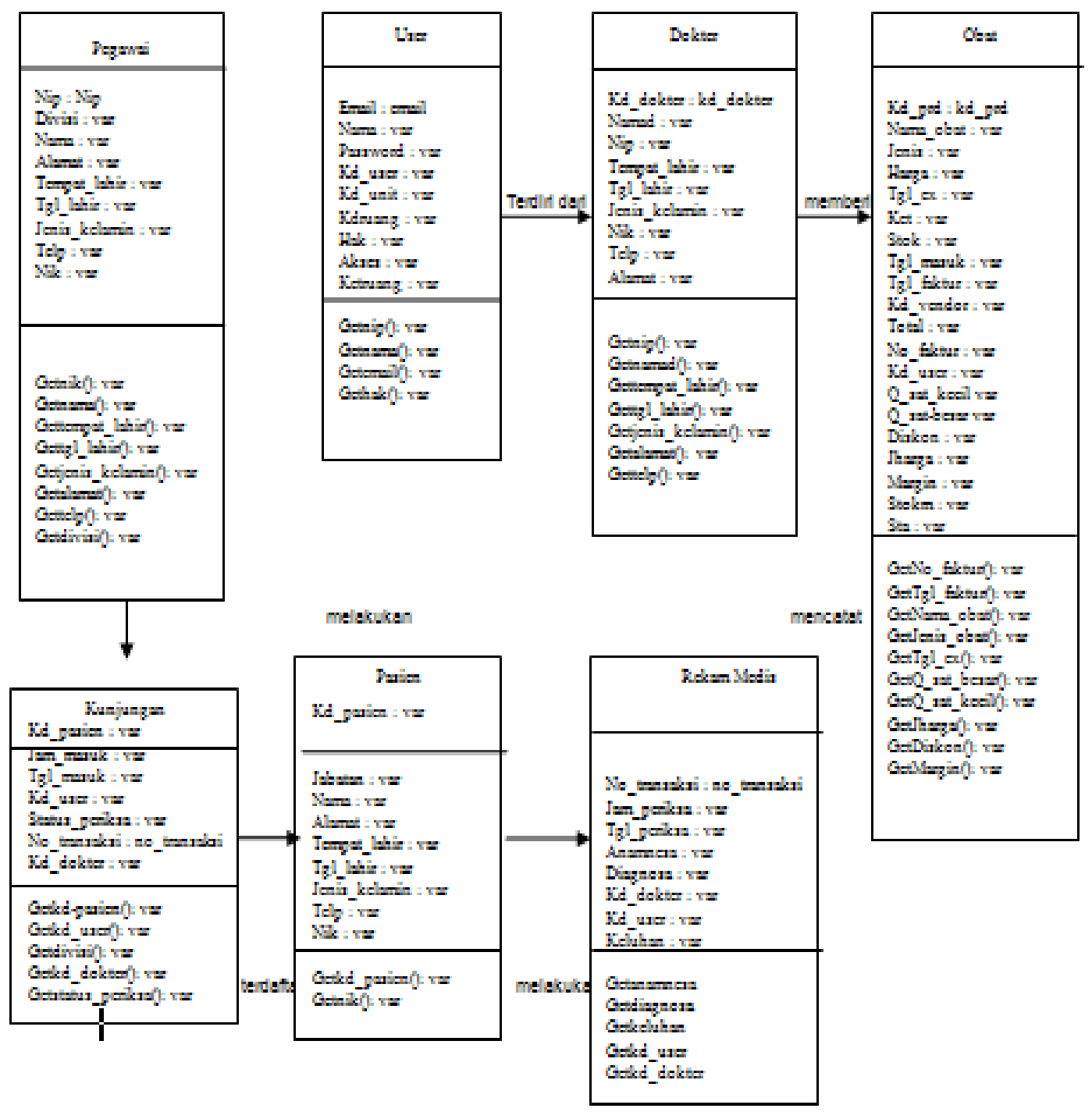

Sumber: Hasil Penelitian (2020)

Gambar 4. Class Diagram 


\section{Sequence Diagram}

Sequence Diagram biasa digunakan untuk menggambarkan Bahasa atau rangkaian langkah-langkah yang dilakukan sebagai respons dari sebuah event untuk menghasilkan output tertentu. Diagram ini menunjukan sejumlah contoh obyek dan message yang diletakkan di antara objek-objek di dalam use case.

Berikut dibawah ini Sequence Diagram dari Sistem Informasi Rekam Medis Pada Klinik PT. Nippon Paint Jakarta:

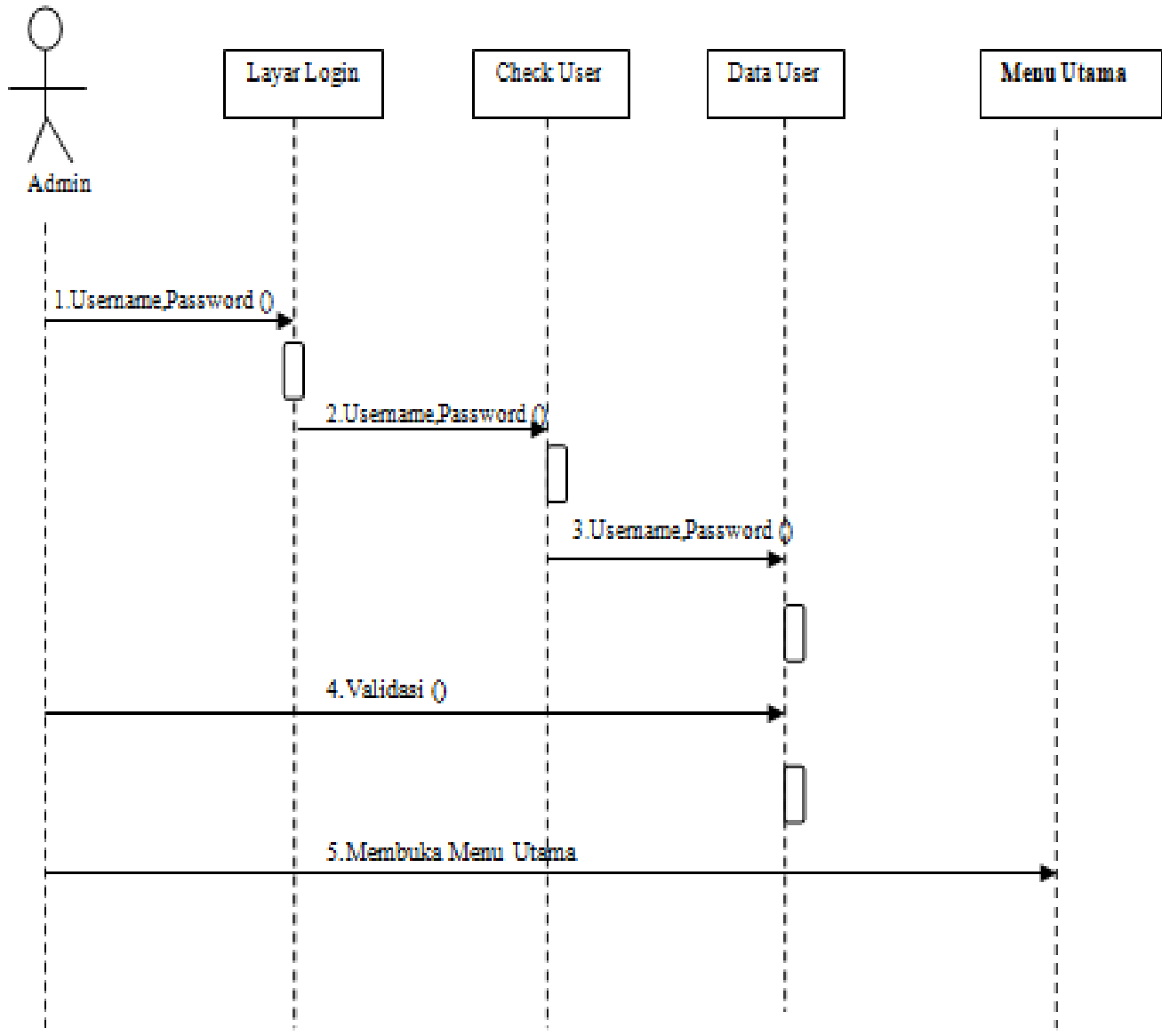

Sumber: Hasil Penelitian (2020)

Gambar 5. Sequence Diagram Admin Melihat Transaksi

\section{E. Deployment Diagram}

Deployment Diagram menggambarkan proses - proses berbeda suatu sistem yang berjalan dan bagaimana relasi di dalamnya. Deployment Diagram juga digunakan untuk menunjukan konfigurasi komponen dalam proses eksekusi aplikasi dan digunakan juga untuk memodelkan: Sistem tambahan (embedded system) yang menggambarkan rancangan device, node, dan hardware, sistem client/server, sistem terdistribusi murni, serta rekayasa ulang 
aplikasi. Deployment diagram Sistem Informasi Rekam Medis Pada Klinik PT. Nippon Paint Jakarta dapat dilihat pada gambar 6 .

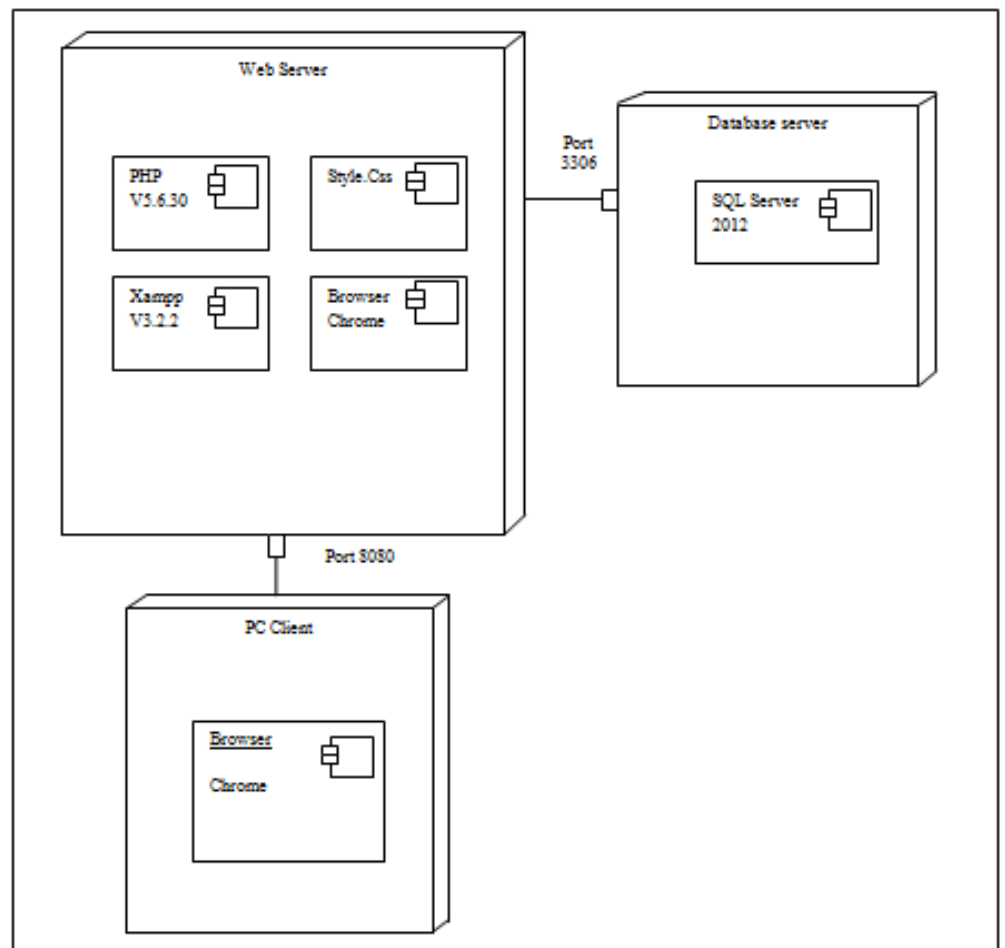

Sumber: Hasil Penelitian (2020)

Gambar 6. Deployment Diagram

\section{F. Component Diagram}

Component Diagram dibuat untuk menunjukan organisasi dan ketergantungan diantara kumpulan komponen dalam sebuah sistem. Diagram ini lebih focus kepada komponen sistem yang dibutuhkan dan ada di dalam sistem. Component diagram Sistem Informasi Rekam Medis Pada Klinik PT. Nippon Paint Jakarta dapat dilihat pada gambar 7.

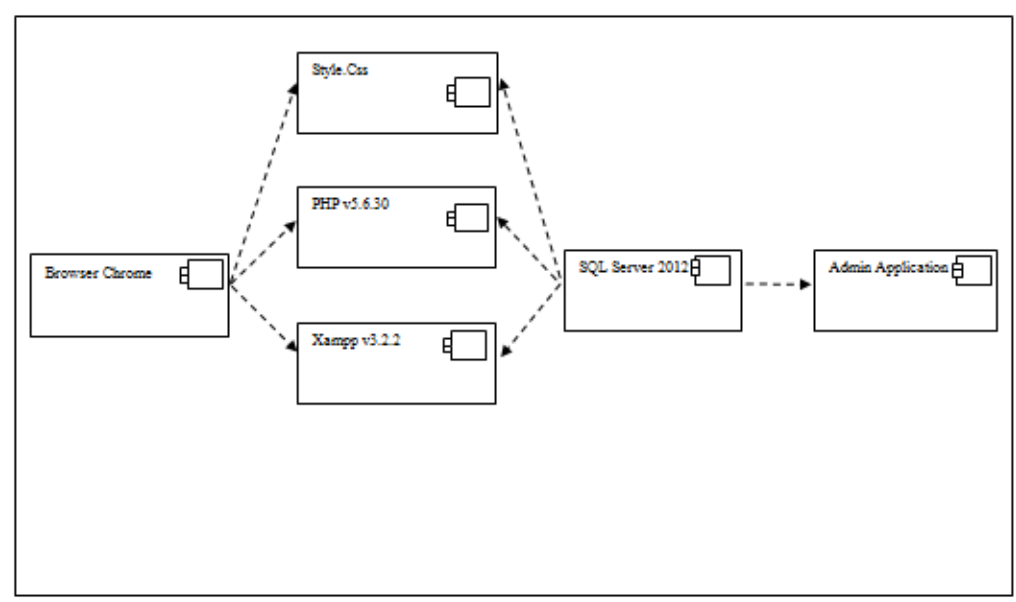

Sumber: Hasil Penelitian (2020)

Gambar 7. Component Diagram 


\section{G. Pengujian (Black Box Testing)}

Black Box Testing berfokus pada spesifikasi fungsional dari perangkat lunak. Testing dapat mendefinisikan kumpulan kondisi input dan melakukan pengetesan pada spesifikasi fungsional program. Berikut Black Box Testing Halaman Login Admin.

Tabel 1. Tabel Hasil Pengujian Black Box Testing Halaman Login Admin Klinik.

\begin{tabular}{|c|c|c|c|c|c|}
\hline No. & Uji Skenario & Test Case & Hasil Yang Diharapkan & $\begin{array}{c}\text { Hasil } \\
\text { Uji }\end{array}$ & Ket \\
\hline 1 & $\begin{array}{l}\text { Mengosongkan } \\
\text { username dan } \\
\text { password kemudia } \\
\text { klik tombol login }\end{array}$ & $\begin{array}{l}\text { Username: } \\
\text { (kosong) } \\
\text { Password: } \\
\text { (kosong) }\end{array}$ & $\begin{array}{l}\text { Sistem akan menolak akses } \\
\text { dan menampilkan "please fill } \\
\text { out this field" }\end{array}$ & Sesuai & Valid \\
\hline 2 & $\begin{array}{l}\text { Hanya mengisi } \\
\text { username } \\
\text { kemudian klik } \\
\text { tombol login }\end{array}$ & $\begin{array}{l}\text { Username: } \\
\text { Admin (benar) } \\
\text { Password: } \\
\text { (kosong) }\end{array}$ & $\begin{array}{l}\text { Sistem akan menolak akses } \\
\text { dan menampilkan "please fill } \\
\text { out this field" }\end{array}$ & Sesuai & Valid \\
\hline 3 & $\begin{array}{l}\text { Hanya mengisi } \\
\text { password kemudia } \\
\text { klik tombol login }\end{array}$ & $\begin{array}{l}\text { Username: } \\
\text { (kosong) } \\
\text { Password: } \\
\text { Admin (benar) }\end{array}$ & $\begin{array}{l}\text { Sistem akan menolak akses } \\
\text { dan menampilkan "please fill } \\
\text { out this field" }\end{array}$ & Sesuai & Valid \\
\hline 4 & $\begin{array}{l}\text { Mengetikan } \\
\text { username atau } \\
\text { password dengan } \\
\text { kondisi salah satu } \\
\text { data benar dan } \\
\text { satu lagi salah, } \\
\text { kemudian klik } \\
\text { tombol login }\end{array}$ & $\begin{array}{l}\text { Username: } \\
\text { Admin (benar) } \\
\text { Password: } \\
\text { admin (salah) }\end{array}$ & $\begin{array}{l}\text { Sistem akan menolak akses } \\
\text { dan menampilkan "data } \\
\text { yang anda masukan tidak } \\
\text { sesuai" }\end{array}$ & Sesuai & Valid \\
\hline 5 & $\begin{array}{l}\text { Mengetikan } \\
\text { username dan } \\
\text { password dengan } \\
\text { kondisi semua } \\
\text { benar kemudian } \\
\text { klik tombol login }\end{array}$ & $\begin{array}{l}\text { Username: } \\
\text { Admin(benar) } \\
\text { Password: } \\
\text { Admin(benar) }\end{array}$ & $\begin{array}{l}\text { Sistem akan menerima } \\
\text { akses login dan akan } \\
\text { menampilkan "data telah } \\
\text { ditemukan" kemudian masuk } \\
\text { halaman utama }\end{array}$ & Sesuai & Valid \\
\hline
\end{tabular}

Sumber: Hasil Penelitian (2020)

\section{H. User Interface}

Program sebagai kumpulan dari instruksi atau perintah yang sudah disiapkan sehingga dapat melakukan fungsi sebagaimana baik yang telah ditentukan. Tujuan pembuatan program 
ini adalah untuk mempermudah dan mempercepat aktivitas yang berhubungan dengan pengolahan data.

\section{Pendaftaran Pasien}

Perancangan ini nantinya akan digunakan oleh calon pasien untuk mendaftarkan dirinya ke Klinik PT. Nippon Paint Jakarta Adapun rancangan gambarnya sebagai berikut :

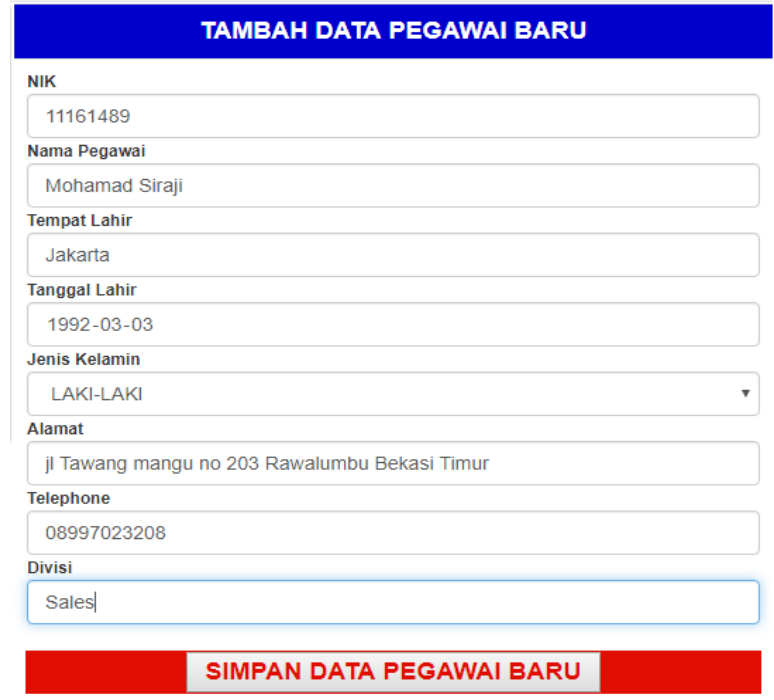

Sumber: Hasil Penelitian (2020)

Gambar 8. Form pendaftaran Pegawai melalui HRD/kepala Klinik.

\section{Pendaftaran Kunjungan Pasien}

Pasien berkunjung untuk melakukan pemeriksaan ke Klinik PT. Nippon Paint Jakarta dan di gunakan oleh Admin Klinik untuk keperluan Rekam Medis sebagai berikut :

\section{PENDAFTARAN KUNJUNGAN PASIEN}

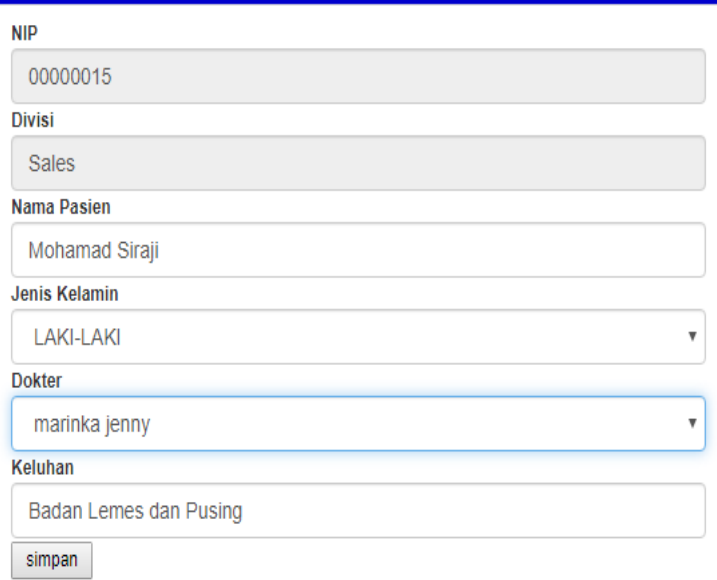

Sumber: Hasil Penelitian (2020)

Gambar 9. Form pasien untuk kunjungan pertama pada Admin Klinik. 


\section{Kesimpulan}

Berdasarkan pembahasan yang telah penulis jabarkan mengenai pembuatan Sistem Informasi Rekam Medis Pasien Berbasis Web Pada Klinik PT. Nippon Paint Jakarta, Pendataan rekam medis pasien dilakukan secara manual dengan menggunakan Microsoft Excel, Sehingga pengelolaan data klinik lebih lamban dan kurang efisien dalam kinerja ketika pasien berkunjung untuk melakukan pemeriksaan.Perekapan data dilakukan secara tertulis yang menyebabkan ketika dokter ingin mengontrol perkembangan pasien dalam melakukan rekam medis membuat pencarian data secara manual. Data catatan hasil rekam medis berupa kertas-kertas di nilai cukup rentan karena suatu ketika rusak atau hilang akan mempersulit proses kinerja. Hasil laporan rekam medis pasien pada Klinik PT. Nippon Paint Jakarta memerlukan ruang penyimpanan berkas, namun membutuhkan ruang dengan muatan yang cukup besar untuk menampung banyak data pasien dan dalam proses yang berlangsung membutuhkan waktu cukup lama saat pencarian data.

\section{Ucapan Terima Kasih}

Penulis mengucapkan terima kasih kepada Pimpinan PT. NIPPON PAINT JAKARTA yang telah memberikan kesempatan pada Penulis untuk melakukan riset di PT. NIPPON PAINT JAKARTA. Penulis juga mengucapkan terima kasih kepada pengelola Jurnal di Universitas Bhayangkara Jaya, yang telah memberikan kesempatan bagi penulis untuk menerbitkan artikel ilmiah di Jurnal ini.

\section{Daftar Pustaka}

Anastasia Diana, L. S. (2011). Sistem Informasi Akuntansi, Perancangan, Prosedur dan Penerapan.

Peraturan Menteri Kesehatan Republik Indonesia. Nomor 269/MENKES/PER/III/2008. Tentang.

Rekam Medis. (n.d.). http://pelayanan.jakarta.go.id/download/regulasi/peraturan-meneterikesehatan-nomor-269-tentang-rekam-medis.pdf

Peraturan Pemerintah Republik Indonesia Nomor 47 Tahun 2016 Tentang Fasilitas Pelayanan Kesehatan. (n.d.). https://www.persi.or.id/images/regulasi/pp/pp472016.pdf).

Siswanti, D. A. D. (2019). Tinjauan Aspek Keamanan dan Kerahasiaan Rekam Medis di Rumah Sakit Setia Mitra Jakarta Selatan. Jurnal Rekam Medis Dan Informasi Kesehatan, 2(2), 19. https://doi.org/http://dx.doi.org/10.31983/jrmik.v2i2.5349

Sukamto, R. A., \& Shalahuddin, M. (2013). Rekayasa Perangkat Lunak. Informatika.

Susanto, E. (2018). Sistem Informasi Pembayaran SPP Berbasis WEB di MTS BAITTURAHMAN Beringin Taluk. Perencanaan, Sains, Teknologi, Dan Komputer, 1(2), 141-146. https://ejournal.uniks.ac.id/index.php/JUPERSATEK/article/view/167/121

Yusrizal, Rahmad Dawood, dan R. (2017). Rancangan Bangun Layanan Web Untuk Aplikasi 


\section{Mohamad Siraji, Heri Kuswara}

Rekam Medis Praktik Pribadi Dokter. Jurnal Online Teknik Elektro, 2(1), 1-8. http://jurnal.unsyiah.ac.id/kitektro/article/view/6803/5571 